\title{
The State and the City, the State in the City: Another Look at Citadinité
}

\author{
Noémi Léry-Aksu
}

At the core of this volume and the ambitious collective research project to which it belongs, the notion of citadinité calls for a new approach to the history of Jerusalem from 1840 to 1940. The localization and analysis of a wide range of archival sources aim to shed light on the institutions, actors, and practices that shaped the city throughout the period and defined its complex identity. The comprehensive collection of archives gathered for the project makes it possible to explore the connections and tensions between the polyphonic - not to say cacophonic - narratives that have accumulated for more than a century and to make room for forgotten voices. Beyond that, the combination of state, municipal, community, and private documents offers exceptional insight into the functioning of different institutions and groups settled in the city, and their interactions, both in everyday life and under exceptional circumstances. Despite being a city of its own, Jerusalem can be studied in a comparative perspective. This approach, in return, contributes to a broader conceptualization of citadinité. In this light, the current chapter discusses one aspect of the "documentary archipelago" available to scholars working in Mediterranean, Ottoman, and/or colonial cities: the presence of the state and its role in the construction of urban identities at the turn of the twentieth century. ${ }^{1}$

For several decades now, the historiography of Ottoman cities has been profoundly renewed. Reacting against the Weberian conceptualization of the Islamic city, historians of late Ottoman Arab, Anatolian, and Balkan cities have emphasized the political, social, economic, and cultural changes these cities underwent in the nineteenth century. ${ }^{2}$ Among them, the creation of

1 I borrow the expression "documentary archipelago" from the introduction of the volume and the description of the Open Jerusalem project in its website (www.openjerusalem.org).

2 Max Weber, The City (1922; repr. Glencoe: Free Press, 1958) According to Weber, the Islamic city lacks the main characteristics that define the city in its Western conception collective identity, political autonomy and civic culture. Weber emphasized the fragmentation of the Islamic city and its resistance to change.

(C) NOÉMI LÉVY-AKSU, 2018 | DOI:10.1163/9789004375741_011

This is an open access chapter distributed under the terms of the prevailing CC-BY-NC-ND License at the time of publication. 
municipalities has been singled out as the sign of a new approach to urban administration and citizenship. ${ }^{3}$ Acting as interfaces between the state and the city dwellers and reflecting the shared - and sometimes conflicting - interests of notables coming from diverse ethno-religious backgrounds, the municipal councils offer a privileged standpoint from which to discuss local politics, urban autonomy, and city administration in the late Ottoman context. ${ }^{4}$ Yet, municipalities were not the only institution that contributed to the transformation of the urban space and administration in the late nineteenth to early twentieth centuries. More than anything else, municipal archives highlight the multiple levels of interaction between a wide range of community organizations and private actors as well as state institutions. ${ }^{5}$ While the endogenous character of the community organizations and private actors leaves no doubt as to their role in the constitution of new urban identities, the connection between state institutions and the concept of citadinité is more problematic. The control exercised by governmental authorities certainly curbed the development of autonomous Ottoman municipalities and limited the scope of their activities; yet state reforms in infrastructure, education, justice, and security also contributed to transforming the relations between city dwellers and the urban space, often in convergence with the municipal authorities.

Much has been written on the relations between the Ottoman central state and the cities, especially in the case of the Arab provinces. ${ }^{6}$ While the centralization versus decentralization debate has largely died down, there is still little

3 While officially institutionalized through the provincial reforms promoted by the Ottoman state during the Tanzimat period, the municipalities also built on older traditions of local administration. See Nora Lafi, ed., Municipalités méditerranéennes: Les réformes ottomanes au miroir d'une histoire comparée (Moyen-Orient, Maghreb, Europe méridionale) (Berlin: Klaus Schwarz, 2005).

4 Unfortunately, few municipal archives have been preserved. Besides Jerusalem's municipal archives, there are the archives of Thessaloniki, Nablus and Bursa, which still await comprehensive studies. See also the chapter by Mahmoud Yazbak, "Comparing Ottoman Municipalities in Palestine: The Cases of Nablus, Haifa and Nazareth, 1864-1914," in this volume. Robert Ilbert's work on Alexandria remains a central reference to reflect on municipal institutions and political transitions in multicultural Mediterranean cities. Robert Ilbert, Alexandrie, 1830-1930: Histoire d'une communauté citadine, 2 vols. (Cairo: Institut français d'archéologie orientale (IFAO), 1996).

5 Yasemin Avcı, Vincent Lemire, and Falestin Naïli, "Publishing Jerusalem's Ottoman Municipal Archives (1892-1917): A Turning Point for the City's Historiography," Jerusalem Quarterly, no. 60 (2015).

6 Jens Hanssen, Thomas Philipp, and Stefan Weber, eds., The Empire in the City: Arab Provincial Capitals in the Late Ottoman Empire (Wurzburg: Ergon, 2002). 
consensus as to the nature of Ottoman rule in the provinces. Approaches emphasizing patterns of cooperation between the central and the local are challenged by the colonial paradigm developed by Ussama Makdisi and others. ${ }^{7}$ Without directly addressing this debate, this chapter proposes a few possible avenues by which to question the connections between state intervention and citadinité in the late Ottoman period. Arguing that, in many cases, the distinction between the central and the local was far from clear-cut, I propose to focus rather on the integration of state actors in the urban fabric and their interactions with local people. The first part of the chapter is a brief assessment of the literature on the state presence in late Ottoman cities. It contrasts the numerous studies on public spaces and monuments with the relative lack of interest in the functioning and staff of the state institutions on the ground. The second part is a case study drawn from my personal research on the late Ottoman police forces. In it, I discuss their integration in the urban space as well as their role in enforcing a certain idea of public order through mechanisms of cooptation and repression. Through this case, I argue that state-society and central-local oppositions are less relevant to the discussion of citadinite than a careful analysis of the patterns of alliances and exclusion that legitimized some actors and practices while marginalizing others.

\section{The State in the City: A Historiographic Survey}

The historiography on late Ottoman cities has grown so fast in the last decades that a comprehensive survey of it would be beyond the scope of this chapter. While this new literature owes much to the broader transformations in urban historiography all over the world, its main research questions are also shaped by a critical approach to academic and political traditions that have prevailed in the field for decades. Rejecting the Weberian model of the Islamic city as well as other orientalist approaches to Middle Eastern geographies, recent scholarship on Balkan and Arab cities has also distanced itself from a nationalist perspective on the Ottoman past, questioning the imprint of the Ottoman state with new theoretical and methodological tools. While important differences, and even divergences, persist in the evaluation of the role of the Ottoman state in the provincial cities, the following survey will attempt to provide insight into the conceptualization and analysis of the state presence in urban space.

7 Ussama Makdisi, “Ottoman Orientalism," American Historical Review 107, no. 3 (2002). 
From a theoretical perspective, the discussion of the Ottoman state in urban historiography has been framed more by the broader debate on Ottoman reforms and provincial rule than by a reflection on the specific urban framework. Beyond the shared assumption that state control over the provinces increased in the second half of the nineteenth century and culminated during the reign of Abdülhamid II, scholars disagree on the political meaning of this enhanced state presence. Referring to James Scott, Michael Mann and Michel Foucault, historians of Beirut, Thessaloniki, and Izmir have emphasized the new approaches to power and governance linked to the transformations of the state. ${ }^{8}$ The development of an infrastructural power relying on a network of institutions in charge of education, security, health, and public infrastructures made the state more visible at the local level and enabled it to monitor its subjects in a much more efficient way. While this approach offers a general framework to analyze comparatively the transformations in provincial administration in the late nineteenth to early twentieth centuries, recent studies of late Ottoman cities are careful to articulate this project of Ottomanization with the distinctive local dynamics of each city. The older traditions of local administration, the role of the notables, and the spread of capitalism associated with the colonial ambitions of European powers converged or concurred with state intervention to transform the urban space and social relations.

While this approach prevails in the studies of Balkan and Anatolian cities, including the Ottoman capital, in the case of Arab cities it is challenged by a more critical approach to what is perceived as the Ottoman state's increasingly colonial form of rule. Although the two approaches are not exclusive, the colonial paradigm, which has come to bear on a number of studies on late Ottoman Arab cities and provinces, questions the Orientalist stance of the Ottoman bureaucratic elites and its connections with European imperialism. Arguing that "the nineteenth-century Tanzimat reflected the birth

8 See, for instance, Eugene L. Rogan, Frontiers of the State in the Late Ottoman Empire: Transjordan, 1850-1921 (Cambridge: Cambridge University Press, 1999), 1-20; Maurus Reinkowski, "The State's Security and the Subjects' Prosperity: Notions of Order in Ottoman Bureaucratic Correspondence (19th century)," in Legitimizing the Order: The Ottoman Rhetoric of State Power, ed. Maurus Reinkowski and Hakan T. Karateke (Leiden: Brill, 2005); Jens Hanssen, Fin de Siècle Beirut: The Making of an Ottoman Provincial Capital, (Oxford: Oxford University Press, 2005), 1-21; Sibel Zandi-Sayek, Ottoman Izmir: The Rise of a Cosmopolitan Port, 1840-1880 (Minneapolis: University of Minnesota Press, 2012). Some of the theoretical references frequently used are James C. Scott, Seeing Like a State: How Certain Schemes to Improve the Human Condition Have Failed (New Haven: Yale University Press, 1998); Michael Mann, "The Autonomous Power of the State: Its Origins, Mechanisms and Results," in States in History, ed. John A. Hall (Oxford: Blackwell, 1989). 
of a distinctly modern Ottoman imperialism," Ussama Makdisi has emphasized the construction of a cultural and racial difference between the central elites and the local population as well as the violent aspects of Ottoman domination. ${ }^{9}$ In this framework, the Ottoman imperial project in the Arab provinces is conceived as an effort to counter European attempts at cultural and political domination. While reframing the modernizing project of the Ottoman state from a perspective which draws on Edward Said's analysis of orientalism and postcolonial studies, this approach paradoxically brings back some "old" concepts as well: Makdisi's emphasis on the "Arab periphery" reactivates the geographic distinction between the Arab lands and the other provinces and revives the center-periphery model from a new angle. ${ }^{10}$ This paradigm has inspired a number of attempts to broaden the geographic scope of the center-periphery model, add nuance to its argumentation and, in some cases, question its very validity.11

Despite their differences and divergences, these approaches converge in their interest in the cultural forms of Ottoman rule in the provinces and their sensibility to public space and architecture in the urban fabric. The concept of "public space" has been increasingly discussed from a theoretical and urbanistic perspective with specific reference to transformations in urban fabric. According to Shirine Hamadeh, urban and suburban environments created by the ruling class, such as public gardens or squares, facilitated a process of décloisonnement, characterized by increased contact between social classes, but also tighter regulations to maintain hierarchies and social order. ${ }^{12}$ Developed with reference to eighteenth-century Istanbul, this conceptual framework is not only a call to rethink the periodization of urban change and

Ussama Makdisi, "Rethinking Ottoman Imperialism: Modernity, Violence and the Cultural Logic of Ottoman Reform," in The Empire in the City: Arab Provincial Capitals in the Late Ottoman Empire, ed. Jens Hanssen, Thomas Philipp, and Stefan Weber (Wurzburg: Ergon, 2002), 30.

$10 \quad$ Makdisi, "Ottoman Orientalism."

11 Thomas Kuehn, Empire, Islam and Politics of Difference: Ottoman Rule in Yemen, 18491919 (Leiden: Brill, 2011); Isa Blumi, Rethinking the Late Ottoman Empire: A Comparative Social and Political History of Albania and Yemen, 1878-1918 (Istanbul: Isis Press, 2010). Özgür Türesay's critical evaluation of Ottoman orientalism questions this geography of difference and draws attention to similar discourses and politics targeting specific ethnicreligious and social categories. See Özgür Türesay, "L'Empire ottoman sous le prisme des études postcoloniales: À propos d'un tournant historiographique recent," Revue d'histoire moderne et contemporaine 6o, no. 2 (2013).

12 Shirine Hamadeh, The City's Pleasures: Istanbul in the Eighteenth Century (Seattle: University of Washington Press, 2007). 
to nuance the novelty of the Tanzimat period. It is also an opportunity to analyze transformations in the urban fabric as part of a broader reconfiguration of power relations and social interactions in nineteenth-century Ottoman cities.

The historiography of the Tanzimat period has singled out urban reforms as one of the main aspects of the modernizing project of the Ottoman state. From the widening of streets to the regulations on buildings, the regularization and modernization of the urban fabric was a core concern for the bureaucratic elite, who aimed to create healthier and safer cities and fight recurrent challenges such as fires, epidemics and riots. ${ }^{13}$ These reforms shared many features with the urban reforms achieved in European cities during the same period. They facilitated the emergence of more connected cities, where both opportunities of interclass, and intercommunal contacts, and capacity of the state to monitor them, were increased. Beyond urbanism, the transformations in provincial administration and new infrastructures also contributed to the creation of new kinds of public buildings that stood out in the urban space. Through these landmarks, the state became more visible in the public space, while opportunities for interaction between city dwellers of different backgrounds and members of state institutions increased.

Several studies have approached these buildings as symbols of power that materialized the state presence in the urban space and created a more immanent dimension to political authority. This aspect is at the core of Selim Deringil's work on Abdülhamid II and the legitimization of power, which emphasizes how architectural forms and ceremonials made the "hidden sultan" present in his absence. ${ }^{14}$ Among these symbols, Deringil pays special attention to clock towers, which dominated the urban fabric as a result of their height. Clock towers helped to introduce a new conception of time and were a convenient meeting point for city dwellers. ${ }^{15}$ Designed as symbols of power, many of these buildings were inaugurated with public ceremonies on significant dates such as the sultan's birthday or his jubilee. From a historiographic perspective, the concentration of interest in clock towers, more often studied than other kinds of public buildings such as hospitals, schools or caserns, is

13 There is an impressive literature on urban reforms and urbanism during the Tanzimat era. See, for instance, Paul Dumont and François Georgeon, eds., Villes ottomanes à la fin de l'Empire (Paris: L'Harmattan, 1992); Zeynep Çelik, The Remaking of Istanbul: Portrait of an Ottoman City in the Nineteenth Century (Seattle: University of Washington Press, 1986).

14 Selim Deringil, The Well-Protected Domains: Ideology and Legitimation of Power in the Ottoman Empire, 1876-1909 (London: I. B.Tauris, 1998).

15 Ibid., 29-30; Avner Wishnitzer, Reading Clocks, Alla Turca: Time and Society in the Late Ottoman Empire (Chicago: University of Chicago Press, 2015). 
emblematic of the main angle under which the imprint of the state in the urban space is approached. That is, the emphasis is laid on visibility and symbolism, while the inner architecture of the public buildings, their functionality, and their accessibility to the city dwellers remain little discussed.

The sources available on late Ottoman cities can at least partly account for this historiographic orientation. The material imprint of the imperial presence in the cities is the most tangible testimony of the Ottoman past in the provincial cities, from the Balkan to the Arab provinces. Although conflict, destruction, and rebuilding following political changes have deeply modified the urban fabric, every post-Ottoman city retains single or numerous vestiges of its imperial past. Interdisciplinary approaches combining art history, archeology, and architecture have placed material culture at the core of their analyses. In many cases, they also rely on photography, not only for its documentary value but also as a precious source, to understand how the Ottoman state, local actors, and foreign observers perceived and represented the city. In this respect, Abdülhamid II's photographic albums offer an extremely rich sample of public buildings and ceremonials in the late Ottoman cities. They convey a project of imperial self-representation that occupied the many faces of the modernizing state. As Wolf-Dieter Lemke underlined in the case of Arab cities, these photographs revealed "a military or administrative eye" at work, which emphasized order and regularity, while showing little of the inhabitants of the city and their daily uses of the urban space. ${ }^{16}$

The main risk of this approach is a reification of the urban space, which sometimes fails to connect the urban fabric and buildings with the social dynamics that inhabitants both witnessed and created. ${ }^{17}$ While recent years have seen innovative approaches to social diversity, marginality and mobility, state institutions and actors have been little explored. ${ }^{18}$ Who worked in the public administration and services that were modernized or created in the late Ottoman cities? What kinds of interactions and encounters occurred in the

16 Wolf-Dieter Lemke, "Ottoman Photography: Recording and Contributing to Modernity," in The Empire in the City: Arab Provincial Capitals in the Late Ottoman Empire, ed. Jens Hansen, Thomas Philipp, and Stefan Weber (Wurzburg: Ergon, 2002), 247.

17 A similar concern is expressed in the introduction of Hanssen, Philipp, and Weber, The Empire in the City: Arab Provincial Capitals in the Late Ottoman Empire, ed. Jens Hanssen, Thomas Philipp, and Stefan Weber (Wurzburg: Ergon, 2002), 17-25.

18 For examples of this new social history of cities, bringing to the forefront the social margins and the state policy regarding them, see Eugene L. Rogan, ed., Outside In: On the Margins of the Modern Middle East (London: I. B. Tauris, 2002); Ulrike Freitag, Malte Furhmann, Nora Lafi, and Florian Riedler, eds., The City in the Ottoman Empire: Migration and the Making of Urban Modernity (London: Routledge, 2011). 
public buildings and in the broader urban fabric? Besides the strong figures of governors who marked the history of the provincial cities, we know little about the anonymous figures working in state administration and involved in daily interactions with the urban dwellers. The Ottoman personnel records (sicil-i ahva $\bar{a} l$ ) contain precious information about the geographic background, education, and career of civil servants but it is difficult to single out cohorts of local bureaucrats unless information is correlated by other sources such as the annuaires orientaux. ${ }^{19}$ To what extent did local recruitment prevail? What were the educational, social background, and ethno-religious distributions of state employees? While these questions are central to discussing the colonial paradigm and patterns of integration, few answers are available.

Ottoman urban history still lacks a social history of institutions that would consider them beyond their symbolic role or official function, as living bodies with porous borders, integrated in the local configuration at multiple levels. Sources of employment and social mobility for some local inhabitants, the state organizations present in the provincial cities were involved in many services at the core of the everyday life of the urban society but also actively contributed to the symbolic or physical violence targeting individuals and behaviors considered incompatible with the urban order in the making. The second part of this chapter proposes a few ways to analyze these institutions in their urban context by focusing on a specific case: the police forces.

\section{The Police and the City: Public Order as a Shared Value?}

The process that led to the creation of modern police forces in the empire started with the abolition of the Janissaries in 1826 . Policing the cities had been one of the roles of this military corps. ${ }^{20}$ To fill the void left by their suppression, the Polis nizāmnāmesi, issued in 1845, enacted the creation of police forces but the institutionalization of these forces was a long and nonlinear process.

19 The annuaires orientaux were yearbooks published in Istanbul from 1868 to 1939 . While their aim was mainly commercial, they provided comprehensive information about trade and administration in the Ottoman Empire, as well as large listings of the registered inhabitants of Istanbul.

20 Several works published in Turkey during the 1940s gave detailed accounts of the various institutional steps of this process. See, for example, Halim Alyot, Türkiye'de Zabıta [Police forces in Turkey] (Ankara: Kanaat Basımevi, 1947). For a more recent and critical evaluation of the process, see Ferdan Ergut, Modern Devlet ve Polis: Osmanlidan Cumhuriyet'e Toplumsal Denetimin Diyalektiği [The modern state and the police: the dialectics of social control from the Ottoman era to the republic] (Istanbul: Iletişim, 2004). 
The process was accelerated during the reign of Abdülhamid II after the creation of the Ministry of Police (Żaptiye Nezāreti) in 1879. The following section will not focus on these institutional developments per se but rather try to question their impact on late Ottoman cities.

\section{Questions of Sources and Methodology}

Until recently, there have been very few studies on the history of the police and their role in the late Ottoman cities. ${ }^{21}$ Works dealing with urban transformations and social life often devote a few remarks to the topic but one can hardly say that the police have benefitted much from the renewal of urban studies in Ottoman historiography. This relative lack of interest has much to do with the narrow institutional perspective still dominating the historiography of the Ottoman police. While a few recent works on Istanbul have drawn attention to this gap and contributed to filling it, little research has been done on the provincial cities. ${ }^{22}$

The Ottoman archives include many series relevant to the study of policing in the late Ottoman cities, especially for the capital and the main port-cities of the empire. ${ }^{23}$ Yet from a qualitative perspective, these archives have many gaps. Their main flaw is that archives of the local police stations are missing. The available documents are the correspondence between the central police

21 The municipal police, which are beyond the scope of this study, are even less studied than the Ottoman state police. In the case of Istanbul, the lack of the municipal archives makes it difficult to understand the actual role of the municipal forces in policing and social control in the capital. While several Ottoman historians tend to assume that the municipal police were weak and under the tutorship of the state police, the Jerusalem municipality archives may shed light on this poor relation of urban studies.

Noémi Lévy-Aksu, Ordre et désordres dans l'Istanbul ottomane (1879-1909) (Paris: Karthala, 2013); İlkay Yllmaz, Serseri, Anarşist ve Fesadın Peşinde: Abdülhamid Dönemi Güvenlik Politikaları Ekseninde Mürur Tezkereleri, Pasaportlar ve Otel Kayıtları [In search of anarchist and mischief: internal passports, passports and hotel registers through the security policies during the Abdülhamid II era] (Istanbul: Tarih Vakfı, 2014); Nurçin İleri, "A Nocturnal History of Fin de Siècle Istanbul" (PhD diss., Binghamton University, 2015).

23 For the reign of Abdülhamid II (1876-1909), the archives of the Ministry of Police (Zabtiye Nezareti, воА.Zв) offer a great number of documents, both for the capital and the provincial cities. The correspondence between the Ministry of Police and Ylldız Palace, kept in the Ylldız Palace Series (Y.ZB), is also extremely rich, as well as the irade (sultanic decrees) and the correspondence of the Ministry of Justice, Ministry of Foreign Affairs and Ministry of War which highlight the interactions between the police, other state institutions and the foreign representations. 
stations of the capital, the Ministry of Police, and the imperial palace of Ylldız, which offer only synthetic summaries of the cases reported by the local police stations. ${ }^{24}$ The second gap is linked to the lack of some series, removed from the Ottoman archives at an unknown date to be kept at the Directorate of General Security (Emniyet Genel Müdürlüğü, EGM) in Ankara. ${ }^{25}$ No catalogue of these archives is available to "ordinary" scholars, and as such it is hard to know which series are stored there. Nevertheless, publications sponsored by the EGM shed some basic light on one of the most valuable series kept in Ankara: the staff files of the Ottoman and Republican periods. ${ }^{26}$ These files provide crucial information regarding the geographic origin of the policemen, their training, and their career. Denial of access to them does not only make impossible a prosopography of the institution but also constitutes a major obstacle to the understanding of the social dynamics which shaped the activities of the police forces and their relations with the people in the late Ottoman cities.

\section{The Police Stations in the Urban Space: A New Kind of Public Buildings}

The institutionalization of police forces had a direct impact on the urban fabric: police stations (karakol) started to be disseminated in the cities. These buildings were an important aspect of the transition from military to civil policing in the nineteenth century. Many caserns, which hosted the Janissaries, were destroyed after their suppression. Smaller wooden buildings were converted into police stations, but these did not suffice to cover the whole city. During the 1830 s, while the reorganization of policing was still in its infancy, new karakol started to be built in the Ottoman capital. The process accelerated in the mid-nineteenth century and culminated under the reign of Abdülhamid II and the early Young Turk period. In most of the provincial cities and towns, caserns and the governor's house hosted the police

24 I will come back to the limits and resources of this documentation for an interactionist perspective on policing in the last part of this chapter.

25 Unfortunately, the research and documentation center located in the buildings of the directorate is only open to the members of the police (students and instructors in the police academy or police institutes) and the few lucky academics who benefit from special authorization.

26 Eyüp Şahin, Türk polisinden seçkin biyografiler [Selected biographies of the Turkish police] (Ankara: Emniyet Genel Müdürlüğü, 2012). 
forces until the late $1870 \mathrm{os}$, when karakol started to become a widespread kind of public building. ${ }^{27}$

The construction of police stations was not only the consequence of the reorganization of the police forces, but also a component of the transformation of the urban space promoted during the Tanzimat period. Numerous instructions emphasized the necessity of building the new police stations according to the architectural and urbanistic principles promoted to order the urban fabric and protect the cities against devastating fires. Like the other public buildings, police stations were considered as signs of modernity and much attention was devoted to their architecture. However, the cost of such buildings prevented their diffusion throughout the city. ${ }^{28}$ In the early twentieth century, there were still wooden police stations, and the reuse of domestic buildings or other kinds of public buildings (schools, military barracks) was a less costly alternative to these architectural projects.

Most of the karakol built in the second half of the nineteenth and early twentieth centuries bore several distinctive features, which singled them out from their environment as public buildings. ${ }^{29}$ Their facade was adorned with the Ottoman coat of arms and the signature (tugrrā) of the sultan who reigned when they were inaugurated. Poems dedicated to the sultan could also be carved on the façade. Characterized by their neoclassical and eclectic styles, the police stations often included columns, pediments, and ornaments, as seen in the photographs from the Abdülhamid II collection. In this regard, beyond their functional role, they became one of the public symbols through which imperial authority became more visible in the urban fabric. Like the clock towers discussed earlier, they participated in the attempts to build a stronger relationship between the sultan, the state, and its subjects through new tools for the legitimization of power.

While these distinctive architectural characteristics facilitated the identification of police stations as public buildings, their integration in the urban fabric was achieved through their proximity to other buildings, such as the mosque, fountain and commercial structures. The proximity to these loci of sociability and gatherings was an asset for surveillance and quick police

27 Omri Paz, "Crime, Criminals and the Ottoman State: Anatolia between the Late 1830 and the Late 186os" (PhD diss., University of Tel Aviv, 2010).

28 Aynur Çiftçi, "Son dönem İstanbul karakolları. Anadolu yakası ve Büyükdere Topçu karakolu" [Police stations in late Ottoman Istanbul: the asian shore and Büyükdere police station] (MA diss., Ylldız Technical University, 1996).

29 The following paragraphs summarize the arguments, which I developed on Istanbul police stations. See Lévy-Aksu, Ordres et désordres, 141-54. 
intervention in case of disorder. Facilitating daily interactions between the police and the people, this spatial integration of the karakol can be observed both in old neighborhoods and in the new districts that developed in the periphery of the cities in the late nineteenth century. In this case, integration appeared as the result of a more conscious effort towards urban planning. For instance, the neighborhood of Sanaye, built in Beirut during the Hamidian period, included "a complex of urban services, including public garden, municipal hospital, prison, and karakol."30 Although the construction of prisons and karakol depended respectively on the Ministries of Justice and Police, they seem to have been integrated here in a municipal project aimed at connecting spaces of services and entertainment in the same area.

The distribution of the police stations in the cities was uneven. The density of population and the socioeconomic characteristics of the neighborhood seem to have played a role in their implantation, but the lack of comprehensive lists and maps makes it difficult to evaluate to what extent the Ottoman authorities consciously planned the distribution of these stations. In the case of Beirut, Jens Hanssen has identified twenty-eight police stations built during the Hamidian period, mostly concentrated in the southern parts of the city in Sunni or mixed neighborhoods, which raised specific challenges to public order. ${ }^{31}$ In Istanbul, my research on the police stations in the district of Tophane-Galata has shown the exceptional density of police stations in this area, especially on the seashore, which hosted port infrastructures and was one of the main entry-points to the capital. ${ }^{32}$ Similar attempts to map the police stations in other Ottoman cities would help understand the strategies of control developed by the Ottoman authorities and correlate the geography of crime and this police concentration.

\section{The Police and the People: The karakol and the Social Integration of the Police}

The role of the police stations in the urban space cannot be evaluated outside the social relations that took place inside and around these buildings. Erving Goffman's 1972 reference work on the police was based on in situ observations

30 May Davie, "Manouk Avédissian, alias Béchar afandi al-mouhandis," in Médecins et ingénieurs ottomans à l'âge des nationalismes, ed. Meropi Anastassiadou (Paris: Maisonneuve \& Larose, 2003), 233.

31 Hanssen, Fin de Siècle Beirut, 207-9.

32 Lévy-Aksu, Ordres et désordres, 289-95. 
that approached the institution and its members through an interactionist perspective, with special emphasis on the micro level. ${ }^{33}$ Obviously, the importance of observation in sociology is a major obstacle to its application to historical topics. Yet the questions raised by Goffman and his emphasis on the tensions and exchanges that characterize the functioning of the police institution can help in exploring the social role of the police in historical contexts. As underlined by Quentin Deluermoz in his study of the nineteenth-century Parisian police, an interactionist perspective on the social dynamics at the core of the police activities may be developed through attention to spatial and temporal details, the actors involved and the physical and verbal interactions mentioned in the police and judicial records. ${ }^{34}$

To what extent can such an approach be relevant to the police in Ottoman cities? The unavailability of local police station archives sets the Ottoman case apart from the French or British ones. If available, the daily logs kept by the karakol would have been the main source for a study of the interactions between the police and city dwellers. Instead, the summaries sent by the central police stations to the Ministry of Police only provide an indirect account of the daily police activities. Yet the recurrence of some places, situations, and tensions makes it possible to get an insight into the role of the police in urban life. Local newspapers also offer a complementary perspective on the Ottoman police activities in the late nineteenth to early twentieth centuries. While the reign of Abdülhamid II was characterized by a widespread use of censorship, this had little effect on the news in brief, which held much space in the newspapers of the capital and provincial cities. Much richer in detail than the police archives, the reports of crimes and incidents gave a sample of everyday violence in the capital. Despite their fragmentary and partial approach to urban realities, these pieces of news still contribute to a better understanding of the temporal, spatial, and social dimensions of policing when they are combined with police records.

These sources offer a view of policing that is more contrasted than the historiography of the Hamidian period. The police, as the main tool of law enforcement and control in the cities, played a major role in the surveillance and repression of "dangerous" individuals and groups in late Ottoman cities. The importance of spying, a mission entrusted both to the police and

\footnotetext{
33 Erving Goffman, Relations in Public: Microstudies of the Public Order (New York: Basic Books, 1972).

34 Quentin Deluermoz, "Usages de Goffman au XIX" siècle: policiers en tenue, institutions et ordres sociaux à Paris," no. 14 (2007).
} 
to a parallel organization of remunerated spies, is attested by a number of archival documents. The political elite and Young Turks were targets, but so too were non-Muslim communities; particularly the Armenians in the capital, and the working classes. Yet the aim of policing was far from limited to the suppression of political threats: like their Western European or Egyptian counterparts, the late Ottoman police devoted much attention to the social and moral challenges to public order. The recurrence of cases involving bachelors (bekār) and prostitutes in police reports and newspapers points to the stigmatization of the supposed moral depravation of these categories and the collaboration of police, notables, and well-settled neighborhood inhabitants in excluding marginal categories. The frontiers between the political, social, and moral threats were often blurred, such as in the case of the control of migrants, a traditional concern for the authorities that grew in urgency with the rise of imperial and transnational mobility. ${ }^{35}$

While a comprehensive study of all these aspects of police activity would be beyond the scope of this chapter, I would like to focus here on one main question raised by these sources: the degree of social integration of the police and the extent to which their utility was acknowledged by the population in the late nineteenth to twentieth centuries. Without underestimating the diversity of the urban contexts, I will discuss a few entries I examined in my research on Istanbul that can be beneficial to consider in a comparative perspective that includes Jerusalem and other late Ottoman cities.

The first entry brings us back to the building of the police stations. The decision to build a new karakol normally resulted from a decision on the part of the Ministry of Police, justified by the absence of similar buildings in the vicinity and/or the specific challenges to public order in a given neighborhood. However, a few cases suggest that city dwellers could also ask for the opening of a karakol in their neighborhood. This was the case in Hasköy, a neighborhood located on the Golden Horn in Istanbul, where members of the Jewish community collected money in 1884 to fund the construction of a station. According to the newspaper Tarik, which gave publicity to this piece of news, this initiative was little appreciated by the Greek inhabitants of the neighborhood. ${ }^{36}$ In 1889, the diary of the mukhtar of Kasap İlyas neighborhood mentioned a petition addressed to the Ministry of Police, signed by some inhabitants asking

36 Tarik, June 11, 1884. The transcription of the article was published in Tarih ve Toplum, no. 4 , June 1984,5 . 
for a police station. ${ }^{37}$ In this case, the mukhtar worked with the inhabitants to identify on a building plot where he suggested that the police build the new station. To what extent were these initiatives exceptional or widespread? Very few similar cases can be found in the Ottoman archives, but since the abovementioned initiatives are not recorded in the Żaptiye Nezāreti series, there may have been other petitions of this kind. In the case of Jerusalem, a few local contributions to the opening of police stations are recorded. In 1903, the engineer Karagüç was awarded by the Ottoman state for having offered half of the funding necessary for the building of four new police stations in the city. ${ }^{38}$ The next year, an Ottoman document acknowledged the role played by the police chief Şevki Bey and the Jerusalem municipality in raising funds to build a gendarmerie karakol in the city. ${ }^{39}$ For this last case, the municipal archives might provide more information on the role of the municipality in the settlement of police and gendarmerie forces in Jerusalem.

Why would urban dwellers support the construction of police stations? This question overlaps with one of the most contested issues in police studies, namely the relationship between the police and the community, and the legitimacy of the institution among the people. It suggests that police forces were considered as urban actors whose social utility was acknowledged by some components of the urban population, even in the repressive framework of Hamidian power. The fear of crime was a main factor in the social demand for police. The local and foreign notables of the city that expressed their views in the local newspapers of late Ottoman cities complained habitually about insecurity, theft and the lack of morality. Their demand for the police was part of a discourse on modernity that called for the replacement of traditional inefficient actors such as night watchmen (bekçi) by modern and competent police forces. This perspective idealized an institution that was still very weakly professionalized. Interestingly, the municipal police did not benefit from the same positive image: harsh criticisms of corrupt and inefficient $\dot{z} \bar{a} b \iota t a$ were recurrent in the same newspapers. The municipality was an easier target than the state institutions in the context of Hamidian censorship. This point of view may, however, also be indicative of the weakness of the municipal police in the Ottoman cities due both to a lack of financial resources and the broad

\footnotetext{
37 Cem Behar, A Neighborhood in Ottoman Istanbul: Fruit Vendors and Civil Servants in the Kasap İlyas Mahalle (Albany: State University of New York Press, 2003), 79.

38 вОА, DH.М Кт 780/57, 1 Şaban 1321 [October 23, 1903].

39 вОА, DH.мКт 8881/14, 5.C. 1322 [July 18, 1904].
} 
attributions given to the state police in terms of urban policing, leaving little space for the development of municipal policing. 40

The late nineteenth-century Ottoman police began to play a role in the settlement of disputes and tensions in the neighborhoods, and this contributed to increasing their legitimacy among local inhabitants. In his article "The Police and the People," Khaled Fahmy relies on the police archives to argue that the late nineteenth-century Egyptian police became an effective mechanism of recourse for ordinary Egyptians, who went to the police stations to seek help in settling legal matters of various kinds, from crime to divorce and inheritance rights. ${ }^{41}$ According to Fahmy, the police were more accessible than the judicial institutions because of their spatial proximity and lower cost. On the other hand, they could avail themselves of the authority of the state, absent in the informal ways of settling conflicts. In the Ottoman case, petitions addressed to the police by local inhabitants on the initiative of the imam and mukhtar give an insight into this recourse to the police to settle minor conflicts. The expulsion of prostitutes or women of ill repute and the closing of taverns were among the objects of these petitions, which were sometimes followed by a police investigation. One of the most documented cases I found for Istanbul was an 1890 petition initiated jointly by the mukhtar and imams of four districts in Tophane, who worked together to gather approximately one hundred signatures mainly from local craftsmen and shopkeepers (eșnăf). The petition demanded police support to set up a local fire brigade (tulumbacı), despite the opposition of the neighboring Galatasaray brigade, which operated in the districts in question. ${ }^{42}$ In this conflict of interests, the police was considered a legitimate arbiter. The file held in the archives reveals that various parties were auditioned by the police (a petition from the adverse party is also found in the file) and an investigation was carried out before the affair was placed before a commission. The result of the commission remains unknown, as is often the case.

While these sources reveal the close relations between some inhabitants and the police, they do not enable us to say with certainty whether the police were able to resolve this sort of local conflict. They also remain silent on why the police were interested in this sort of minor affair and do not give clues about the possible rewards that might stimulate the industriousness of the police officers. Nevertheless, these petitions do seem to indicate that in the

\footnotetext{
$40 \quad$ Lévy-Aksu, Ordre et désordres, $115^{-21}$.

41 Khaled Fahmy, "The Police and the People in Nineteenth-Century Egypt," Die Welt des Islams 39, no. 3 (1999).

42 BOA, Y.PRK.ZB 5/118, 26.M.1308 (H) [11 September 189o].
} 
late nineteenth-century capital, the police had become part of the networks of relations that maintained order and settled disputes in the city. In cooperation with the notables, the religious authorities and the mukhtar, they became one of the options available to inhabitants eager to protect their interests or solve their conflicts. Unfortunately, besides the petitions, the police archives shed little light on the daily encounters between the police and inhabitants. I have suggested elsewhere that their participation in infrajudiciary solutions might also have legitimized their presence in the city neighborhoods and enabled the institution to build a network of personal contacts which could be used for the purposes of surveillance and information gathering. ${ }^{43}$ The validity of such hypotheses for other Ottoman cities, where the density of police stations and number of police per inhabitants were much lower than in the capital, remains to be tested.

\section{Conclusion}

This chapter attempted to provide insight into the historiography of late Ottoman cities by focusing on the presence and role of the state. It argued that, while the scholarship on Ottoman cities has become increasingly interdisciplinary and aware of the significance of material culture, the social history of state institutions remains little studied and integrated in the analysis of urban social and political dynamics. Through the case of the Ottoman police, the chapter addressed the question of the integration of institutions in the urban fabric and the interactions between their members and the rest of society.

To what extent can such an approach contribute to our conceptualization of citadinité in late Ottoman cities? First, the diffusion of police stations and other public buildings was a major aspect of the transformation in the urban fabric. Like schools and hospitals, police stations had both a utilitarian and symbolic function, being the interface between the state and the local population. A better understanding of their interior architecture, accessibility, and their distribution in the cities would contribute to a more nuanced evaluation of the imprint of these buildings on the urban space, and their spatial differences at the infraurban level.

43 Noémi Lévy-Aksu, "Institutional Cooperation and Substitution: the Ottoman Police and Justice System at the Turn of the 19th and 2oth Centuries," in Order and Compromise: Government Practices in Turkey from the Late Ottoman Empire to the Early 21st Century, ed. Marc Aymes, Benjamin Gourisse, and Elise Massicard (Leiden: Brill, 2014), 167. 
The interactions between civil servants and the people also deserve more attention. In the case of the police, the karakol can be considered as a shared space by the different components of urban society, whether they had recourse to the police or were taken into custody. Yet this did not mean that it erased social hierarchies or offered equal resources to all the city's inhabitants. In many cases, the police seemed to encourage or legitimize the social pressure exerted by the local district or some of its inhabitants against behaviors judged contrary to social, moral, and religious conventions, sparing them the bother of a judicial process of uncertain outcome. The arbitrary side of these police interventions was especially detrimental to individuals at the margins of society such as beggars, vagrants, and prostitutes. In the context of social and political tensions, the police could also play a role in the collective stigmatization of specific social categories and outbursts of violence against them, as illustrated by the recurrent instructions regarding the surveillance of Armenians in the Ottoman capital from the 1890 s onwards. ${ }^{44}$ Despite an official ban by the authorities, the use of torture in police stations was a darker side of these interactions between the police and the people. ${ }^{45}$ In this regard, the karakol may help us explore the contrasted facets of late Ottoman citadinité and avoid its idealization: as an interface between the state and the people and as spaces of social encounters, negotiations and violence, police stations offer precious clues about the mechanisms of integration, exclusion, and repression which shaped late Ottoman urban life. Thanks to the Open Jerusalem project and the archives made accessible through it, Jerusalem may become a laboratory for this social history of the police and public order. There is little doubt that the municipal archives, the court registers (sijillāt), and the Ottoman State Archives (Başbakanlık Osmanlı Arşivi) will offer new insights into the role of the imperial and municipal police organizations and the relations between police and justice, thus contributing to a better understanding of power relations and social life in the city.

44 Lévy-Aksu, Ordre et désordres, 156-60.

45 İbrahim Kalkan, "Torture, Law, and Politics in the Late Ottoman Empire, 1840-1918" (PhD diss., New York University, 2015). 